\title{
Lived Experiences of Retrenched Employees Due to the COVID-19 Pandemic in Samar, Philippines
}

\author{
AlvincoT. Porton, Abigail M. Cabaguing,Ph.D. \\ alvinco.porton@ssu.edu.ph, Samar 6700, Philippines \\ abigail.cabaguing@ssu.edu.ph, Samar6700, Philippines
}

\begin{abstract}
The outbreak of the Covid-19 pandemic hampered the economic status of one's state hugely affecting private sectors companies' particular those into providing services and transportation due to the unexpected lockdowns. The study used a descriptive-phenomenological approach in exploring the lived experiences of these retrenched employees in alignment with the study's objective to provide descriptive presentation on how retrenchment affected their well-being and; to understand how they address with the circumstances. Participants were selected using purposive-sampling method identified by the researchers who meet the description of; (a) Age between 20-45; (b) Resident of Catbalogan; (c) working in the private sector particularly providing services like merchandising and transportation; (d) Involuntary retrenched in the midst of Pandemic. From the analysis of data, it was found out that retrenched employees experienced significant difficulties in addressing the implications of retrenchment in providing the needs and support of their families and people who constantly relies on them. Financial strain is the major reason of the distress that these retrenched employees are experiencing thinking how they can provide the needs that affected their families as well. In spite of the challenges, they endured and overcome the difficulties because of their unconditional love for their families and dependents.
\end{abstract}

Keywords: Retrenchment; Pandemic; Economic crisis; Assistance

\section{Introduction}

Early year of 2020, there is an outbreak of a virus which termed as Covid-19. A person who is contracted of this infectious disease can experience mild to severe respiratory illness that can disrupt their daily functioning (WHO, 2020). To date, a total of 44, 748,845 cases recorded worldwide with 13, 406, 223 recovered and 10,9115, 914 total of deaths (WHO, 2020). As a response to control the alarming transmission, unexpected lockdowns was imposed impeding the human mobility.

As recognized by the Department of Trade and Industry (DTI), service sectors which includes transportation is one of the biggest contributors to the GDP of the Philippines which posted the highest share with an average of $61.42 \%$ followed by $28.4 \%$ in the industry an $10.18 \%$ in agriculture recorded in the year 2020 (O’Neill, 2021). But with the sudden surge of cases brought by this pandemic and the continuous limited human mobility, it can be anticipated for the economy to experience deep-freeze in the times of pandemic. 
According to Szmigiera, (2021), although the economic impact of the said pandemic is still uncountable, there is a consensus among economist that the outbreak of the pandemic will mean all advanced economies to suffer rescission this year, with $2.9 \%-4.5 \%$ drop in yearly Gross Domestic Products (GDP) at the world's largest economy. This could mean that even advance countries could not be immune to its economic effect.

It was supported with the study conducted by Chia \& Ker (2020) stating that, workforce retrenchment in Singapore is expected to hit record because of Covid-19 with an estimated by their local economist ranging between 45,000-200,000 retrenchment to be recorded.

In a recent study conducted by Pak \& Adegboye, et al., (2020), they suggested that global financial markets have been heavily impacted by the effects of COVID-19 spread. As the numbers of cases started to increase globally, mainly through the different countries such as US, Italy, Spain, Germany, France, Iran, and South Korea, the world financial and oil markets significantly declined. The result of their study concluded that significant reductions in income, a rise in unemployment, and disruptions in the transportation, service, and manufacturing industries are among the consequences of the disease mitigation measures that have been implemented in many countries.

Given with the literatures presented above, it is the researchers' aspiration to explore the lived experiences of the retrenched employees due to Covid-19 and describe the challenges and changes that retrenchment has incur to these affected employees; and to demonstrate how these retrenched employees addressed and adjusted with the circumstances particularly, in the locality of Catbalogan City.

\section{Methodology}

This section conceptualizes the research design, the instrumentation used in conducting the study and how it was validated to ensure the applicability of the results to its desired population. Additionally, this section also explains of how the gathering of data was conducted.

\subsection{Research Design}

The study was anchored using a qualitative descriptive-phenomenological design. According to Creswell (2007), using qualitative design allows researchers to capture responses that are not measurable using concrete answers. Additionally, using this kind of design is very appropriate especially if the researcher is seeking to understand more than the event but also how the individuals made sense of the event (Maxwell, 1998). Moreover, this methodology also offers insight into how the individual's behavior is influenced by making sense of an event (Maxwell, 1998).

The researchers believe that using this design is the most appropriate for the study in exploring the lived experiences of these retrenched employees.

\subsection{Participants}

The respondents for the study was selected using a purposive sampling in getting the relevant data necessary to serve the purpose of the study. Robinson (2014) defined purposive sampling as a non- 
probability sampling technique that is based on the researcher's judgment to the participant's capability to draw out responses from a certain phenomenon.

A total of 15 respondents participated in the study who qualifies with the researchers' description of the selection criteria which follows;

- Ages 20-45 years' old

- Residing in Catbalogan

- Worked in private companies within Catbalogan premise and;

- Involuntarily retrenched in the midst of Pandemic

Furthermore, the respondents were voluntarily participated in the study and affixed their confirmation by obtaining Informed Consent.

\subsection{Data Gathering Procedure}

In light of finding the essence of the study, the following steps were the undertaking of the researchers with respect of the data collection.

- A semi-structured interview was used for gathering data.

- Instrument used in the study was validated by an expert in the field of research at the same time, a professor in Psychology. This is to secure that the instrument to be used is safe to use and will not contain offensive and misleading questions that will elicit frustrated responses from the participants.

- Interview was conducted through online and phone calls simultaneously, in adherence with the health protocol considering, the pandemic still. This is for the safety of both participants and the researchers from the ongoing pandemic.

- Informed consent was thoroughly explained to the respondents before the interview process and obtained permission to record the conversation.

- Confidentiality was practiced giving maximum-regards with the ethical standards in conducting research.

\subsection{Data Analysis}

The analysis of the data was anchored using Colaizzi's Structure in Data Analysis for Phenomenological Research. Reduction of exhaustive description is the main objective of this method in formulating meaningful description of the respondents lived experience about the phenomenon.

With respect of structured data analysis for the study, the researchers have followed five general steps in the pursuit of analyzing the data. First, it has to do with the formulation of interview guide/questionnaire for the collection of the raw figures following the preparation and organizing of the 
data. Secondly, repeated readings and familiarizing through all the data to procced in generating the important codes. Third, interrelating all the resulting ideas and identify if there is a relevance between the presenting issues so as to create the themes and subtheme for the data. The fourth step, has something to do in categorizing of all data that have collected. Furthermore, after gathering all the figures, dealing with the final resolution to the subject and interpreting the meaning of themes/description is the last undertaking of the researchers for the data analysis.

\subsection{Ethical Consideration}

According to Resnik (2020), conforming to the ethical standards in research increases the quality of the study in providing empirical information, integrity and avoids engaging fallacies of the process. In alignment with this idea, the researchers adhere to ethical considerations indicated in the data gathering section to secure that welfare of participants was protected.

Furthermore, no coercion, involuntary participation or any form has been made during the pursuit of the study.

\section{Results}

This section conceptualizes the results of the data that emerged in the study. Using the respondents' experiences, the phenomenon can be understood and can be explained through the four (4) major themes and eight (8) subthemes that emerged based on the analysis.

Table 1. Summary of Results emerged on the data analysis

\begin{tabular}{lll}
\hline \multicolumn{1}{c}{ Themes } & \multicolumn{1}{c}{ Subthemes } \\
\hline Challenges & $\bullet$ & Psychological Distress \\
& $\bullet$ & Sense of helplessness \\
& $\bullet$ & Economic Strain \\
& $\bullet$ & Unwanted Decision \\
Motivation & - & Unconditional love for the Family \\
& $\bullet$ & Endurance \\
Assistance & $\bullet$ & Compensation \\
& $\bullet$ & Psychosocial support \\
Realization & & \\
\hline
\end{tabular}




\subsection{Theme (1): Challenges}

The challenges of retrenched employees can be explained into four (4) subthemes. These subthemes are; psychological distress, sense of helplessness, economic strain, and resorting to unwanted decisions.

\subsubsection{Subtheme A: Psychological Distress}

Retrenched employees have experienced psychological issues that practically affected their health as well. They experienced anxieties and spent sleepless nights that eventually lead them to lose some weight.

Significant statements that illustrate this subtheme are as follows:

- "I lose my job which resulted me to a lot of adjustments. I have to live with my own need money to pay bills, rental and foods. Because of my overthinking where to get these finances to support my family daily needs, as a bread winner, I have countless of sleepless nights. I lost some weight because of this." [P1]

- "My health was seriously change, depression, anxiety and sleepless night and even feelings of worthlessness came into any circumstances in everyday living. It causes pressure and tension to my family." [P8]

- "Of course, pinaka common gud an financial. Ine gud an pinaka importante labi na yana nga pandemic. Labot pa hine, psychological liwat. Ha pagpininsar nga pano ka makakapgprovide han iyo kada adlaw nga panigastos nga isakto, dre gud ine hoya maupay ha health kay tungod na sobra na pag inover thinking danay nala dre ka na nahihingaturog. (Of course, the most common is financial. Aside from that, psychological as well. Thinking of how to provide enough for the daily expenses is not good for our health because of overthinking which results of being not able to sleep)." [P9]

\subsubsection{Subtheme B: Sense of Helplessness}

Aside from the psychological issues that these retrenched employees have experienced, they also have to deal with the emotional issues resulted from being retrenched. They lost confidence and started doubting their selves.

- "I lost confidence with myself. I felt bit envy to my co-worker they not lose their job even though they only worked for months unlike me who worked many years in their company."[P4]

- "Ha pag pinsaron pala na waray ko trabaho pira ka bulan baga malain akon buot kay di ko mahatag nga sakto an mga kinanglanon nak mga anak asya baga dik nailob makita ira nga mga naaro hin ira gusto pero di ko maihatag ira kay dara nga crisis man. (To think that I don't have a have a job for incoming months, I felt bad because I will not be able to provide 
enough needs of my child so, I can't stand seeing them being not provided of what they want wherein, there is nothing I can do because of pandemic). "'[P3]

- "Of course makuri para akon, lalo na nga nakikiukoy la ako ha akon aunte, financially and emotionally drained (haha), kun kailan I need a job saka lugod ako nawarayan, nakakapanluya gad udog labi na an $1^{\text {st }}$ week nga tambay nala ako ha balay, nagtitinangis la ako. It is hard for me especially that I am just staying with my aunt. Financially and emotionally drained (haha). I lost my job when I need it the most. I felt lethargic especially on the $1^{\text {st }}$ week wherein I am just staying at home, all I did was crying. " [P6]

- "As the bread winner of the family, it cost me a lot of stress. It also affects my self-stem I feel like maybe I'm not good enough that's why my employer decided me to retrenched. I couldn't help myself about my situation that time." [P13]

\subsubsection{Subtheme C: Economic Strain}

The most basic challenge of these retrenched employees faced is the financial. They have to tighten their budget so that they can use their resources longer until they land another job or find another source of income.

- "Bilang usa na empleyado, an mawarayan han trabaho yana na panahon an pinaka makuri na problema kay dida la kami naasa para han pan adlaw adlaw na panigasto, kun waray trabaho maapektuhan kami usa na itu an am pan kaon ha adlaw adlaw. (As an employee, being retrenched is the hardest problem especially in this time of crisis because it is the only resource of my family so; not having a job will affect us and one of these is our food for every day)." [P5]

- "I lose my job which resulted me to a lot of adjustments. I have to live with my own need money to pay bills, rental and foods." [P1]

- "Financially, it affected me very bad. Being retrenched means that I have to adjust with our expenses. Kun dati na mas tipid na kami, I don't know kun paano ko pa ine mas titipiron. (Financially, it affected me very bad. Being retrenched means that I have to adjust with our expenses. We are already tight with our budget back then so, I don't how to make it even tighter)."[P7] 


\subsubsection{Subtheme D: Resorting Unwanted Decision}

Because of the financial strain faced by the family of these retrenched employees, they were left with making decisions even through it violates their will.

Statements that explain this subtheme are as follows:

- "Because of those incomings months without income, I have come into a decision even if it breaks my heart. I decided my senior high school child to stop from his studies. Although it is online, still, it requires expenses for the internet so that he can follow their discussions. "[P2]

\subsection{Theme (2): Motivation}

Despite the adversity that they are experiencing, respondents they are able to find somehow courage and determination to challenge the circumstances for the sake of their families and dependents.

\subsubsection{Subtheme A: Unconditional love for the Family}

Despite of the challenges that these retrenched employees are dealing with, the unconditional love for their family is what pushed them back to stand with their feet again. They did everything according their best to continuously provide for the needs of the family.

- "Ginhuhuna huna ko nala tak pamilya, diri ko nala masyado gindidibdib kay waray naman ako iton mahimo. Instead, an akon nakuha na pan 1-month salary gin invest ko na mag burubaligya ha amon basi mayada kami income kahit papaano. (I thought for my family instead of overthinking of my situation because there is nothing I can do with it, after all. Instead, I invested my 1-month salary on selling something so that I can earn somehow)." [P9].

- $\quad$ "Ha yana namiling nala iba na paagi para may pakaon ko it akon pamilya sugd han panagat ha lawud. Danay, nangungutang la anay para la may maibutang ha lamesa nga pagkaon. (For now, I am finding ways to earn like fishing so that our family could have food to eat. Sometimes, we borrow money so we can put foods in our table). "[P3]

- "Nagtinda po ako para mayda guti na kita kahit papano. In this time of pandemic, it is very important gud na we have income labi na gud kay nagmahal an mga papliton. (I did some selling so that I could earn somehow. In this time of pandemic, it is very important that we have income especially the price of goods increased)." [P11] 


\subsubsection{Subtheme B: Endurance}

These retrenched employees have endured all the challenges because as the bread winner, they are the only hope for the family.

- “Actually, makuri gad. Tungod hine na pagkawaray ko trabaho, nakapangutang ako. Makuri gad labi na kay waray kasiguraduhan yana nga panahon sanglit dre ka maaram pano mo ine mababayaran pero, mag aano-man kay kinahanglan man gud. Yana, gingagamit ko it hiya na puhunan para makabayad ngan makaghatag liwat hit amon pan adlaw-adlaw na kailanganon. (Actually, it very hard. Because of this retrenchment, I loaned. It is very hard especially in this time of uncertainty which you don't know how to repay it however, there is no other choice and it is need. Now, I am using the money as capital so I can pay and provide our daily needs). "[P9]

\subsection{Theme (3): Assistance}

It was a huge relief for the respondents to receive assistance either monetary or non-monetary after the effectivity of their retrenchment. They have somehow managed to proceed with their lives in spite of the circumstances that they have experienced through the assistance that they received.

\subsubsection{Subtheme A: Compensation}

Respondents were also ask whether they received compensation after the being retrenched from their workplace. Some of them received monetary compensation and others received non-monetary assistance that helped them to provide for their family's needs somehow. While some of them are lucky enough to receive compensation from their employers or company, others were unfortunate not receiving any sort of compensation.

- "Fortunately, my company send me financial assistance week after the effectivity of my retrenchment. So, I used the money to capital my small business. I am offering short order snacks with free delivery. Somehow, because of these, I was able to have additional support to provide our needs because my husband's salary is not quite enough for us. '[P2]

- "Kun monetary, waray pero kun mga essential items or goods, mayda. After han pagkatanggal akon, pera la ka adlaw nakarawat ko ine na ayuda. Bisan gad hiya dire sugad ka damo, naappreciate ko liwat adto na ginhatag nira ha akon kay nakabulig gud gihap adto kahit papano. (In terms of monetary, none. But in terms of essential items or goods, there is. Few days after being retrenched, I did receive this assistance. Through its not that big, I still appreciated what they gave me because it will still help somehow.)"[P9]

- “Waray gud sir. (Definitely, none sir.)” [P3] 


\subsubsection{Subtheme B: Family and Friend's Support}

In the pursuit of finding determination of these retrenched employees with their experiences, they are able to have the courage to challenge the circumstances through the support of their families and friends.

- "Some of my friends have side-lines and they let me do as a part time job for their business being a rider and somehow it helps me to overcome my overthinking and being anxious." [P4]

- "What I did, nakipagcommunicate gud ak ha ak husband ngan akon mga trusted ones. Narealized ko nala na nakakarawat ko na an sitwasyon. (What I did, I communicated with my husband and my trusted ones. Then, I just realized that I am starting to accept the situation)." [P7]

- "I was to ask help from my family member and friends that am ready to take any job offer as I expected they never let me down." [P8]

\subsection{Theme (4): Realizations}

After going through the hardships brought by this retrenchment to these employees, they have reflected through these experiences and come into realizations that they can use to improve themselves way better. Significant statements illustrated the followings:

- "One thing that I have learned from these experiences and I can apply to improve my self is that, we should be wise in spending our money and other resources. Back then, I use to spend my money like there is no tomorrow. So, when this retrenchment comes to me, I was shocked and experience great deal of difficulty because I am not prepared for these. "[P1]

- Ine na panhinabo, kinahangkan gud na mag skwela gud. Kun nakatapos la ako siguro ako han akon pag-aram, dre gud ada ako ma-uura2x kay makakabiling man gihap ako iba na masusudlan gihap na mas maupay-upay. Sanglit akon mga anak, gintatalinguha o na pagpaka-skwela gud ngan magpakatapos. Hito naman la nga butang, magiging malipayon ako na dire na hira maabat hin kakurian sugad han akon gin-again. (This happening, I realized that we must attend school. If only I finished my studies, I think it will not be this difficult to find a much better job. That's why, I preserve my child to attend school and finish their studies. In that way, I will be glad that they will not experience as the same of my difficulties I've gone through)." [P3]

- "What I have realized is that we really need to save while mayada nimo kwarta ngan kusog mas maupay nga may makukuhaan ka la geyap ha oras nga kawarayan nimo. (What I have realized is that we really need to save while you have money and strength. It's good that you have something to get in times of need)." [P6] 


\section{Discussion}

The present study aspired to understand and provide descriptive presentation of the experiences of retrenched employees due to pandemic. In addition, the study aimed as well to identify how these retrenched employees adjust with the challenges that resulted from being unemployed and cope with the circumstances they are facing.

Based on the data that was gathered from the present study, four (4) major themes emerged which best described the lived experiences of these retrenched employees and these are, (1) Challenges; (2) Motivation; (3) Assistance; and (4) Realization. These retrenched employees have reported that their experience to deal with the consequence brought by the situation was quite challenging.

The first major theme that emerged in the study is the challenges that they experienced after being retrenched from their workplace. Majority of the respondents have confirmed that they experienced psychological, emotional and financial strains that subsequently resulted them from making inevitable hard decisions. Being retrenched is a constant challenge indeed. According to Chandra (2015), retrenchment causes the person and the family to perceive negatively with their life due to its traumatic effect. Respondents described their experiences owing to retrenchments as an impediment to their holistic development. Significant weight loss, anxiety and restlessness emerged as some of the health issues associated after experiencing retrenchment. They have constantly confirmed that this health implication is in connection with the financial strain that they faced owing with loss of income which means they have to tighten their budget and find ways to provide needs for other basic expenses. Moreover, it was also reported that employees who experienced involuntary retrenchment lost the confidence and perceived negatively unemployment which lowered their self-esteem. This is consistent with idea of Chandra (2015), which explained that retrenched employees view the experience as a one-sided breach of psychological contract with the organization.

Second major theme that emerged in the study is the motivation of the retrenched employees that urged them to keep on going in spite of being in a bind of retrenchment. This theme emphasized the unconditional love of these retrenched employees for their dependent or families. They mustered their strength and courage to challenge the situation rather than being overwhelmed by their own feelings. Respondents have shared that they opted various types of selling to generate income that can support the daily needs and expenses for the family.

In the face of uncertainties, respondents have confirmed that they opted to make hard decisions for their family even owing money and endured all the hardships just to aid their daily needs for they are the only hope of their dependent or families.

Assistance was the focus of the third theme, which included the compensation and the moral support they received in dealing with consequences of retrenchment. Respondents reported different stories of the compensation they received from their company after the effectivity of their retrenchment. Some of them were compensated either monetary or non-monetary assistance however, other were unfortunately of not receiving anything after being involuntary retrenched.

Aside from the compensation they received from their company, respondents also emphasized that moral support from their families and friends played a crucial role as well in finding the determination to support their families who solely depends on them. According to IFRC (2021) psychosocial supports plays 
crucial role in strengthening the mental state of an individual to cope better and handle everyday stress. All of the respondents confirmed that, by communicating with their loved and trusted ones, they are able to challenge the implications of the situation. They realized the strength they need to address the circumstances.

Furthermore, the last major theme that emerged in the study is the realization that they have acquired from being retrenched. The experience they went through thought them life lessons they can use to improve themselves better for future experience. Rather than perceiving the experiences negatively, they realized that we focus on the positivity of these experiences to cope effectively and continue with the challenges of our life.

\section{Conclusion}

After incorporating the themes and findings of the study, it was found out that retrenched employees experienced significant difficulties in addressing the implications of retrenchment in providing the needs and support of their families and people who constantly relies on them. The results showed that financial strain is the major reason of the distress that these retrenched employees are experiencing thinking how they can provide the needs that affected their families as well. Some of the respondents are fortunate to received compensation from their company while other were still hopeful that somehow they will be compensated by their companies.

Overall, retrenched employees endured all the challenges brought by the circumstances with their might and limitation, and appreciated the support they received that helped them reach to realizations of the experiences. Psychological support played a crucial role in the coping and adjustment of these retrenched employees.

\section{Recommendations}

Based on the results of the study, it is humbly recommended that all companies or employers should enforce assistance appropriate for their retrenched employees, may it be monetary or non-monetary to alleviate the burden of their needs.

It is also important that these retrenched employees should constantly communicate with their immediate families and close persons of these so that they would feel supported and cope with the experience effectively.

Additionally, further studies were recommended regarding retrenchment to understand its implications to employees and individual, in general. 


\section{Acknowledgements} endeavor.

The researchers' wishes to express their profound gratitude to the enumerable persons behind this

To the researcher adviser for the immense knowledge and expertise which helped the researchers to generate a quality output;

To the families of the researchers that served as inspiration and motivation along the pursuit of the study;

\section{References}

Chandra, D. (2014). A Study on Socio-economic Impact of Retrenchment on Workers—with Special Reference to Allahabad Retrieved from: https://journals.sagepub.com/doi/abs/10.1177/0258042X14535157

Chia, D. \& Ker, Y. (2020). Retrenchments in Singapore in the Time of Covid-19: Dos and Don'ts for Employers. Retrieved from https://www.morganlewis.com/pubs/2020/05/retrenchments-in-singapore-in-the-time-of-covid-19-dos-and-donts-for-employerscv19-1f

Creswell, J. W. (2007). Qualitative inquiry and research design: Choosing among five traditions. Thousand Oaks, CA: Sage.

International Federation of Red Cross (2021). Psychosocial Support. Retrieved from: https://www.ifrc.org/en/what-we do/health/psychosocial-support/

Maxwell, J. A. (1998). Designing a qualitative study. In L. Bickman \& D. J. Rog (Eds.), Handbook of applied social research methods (pp. 69-100). Sage Publications, Inc

O'Neill, A. (2021). Philippines: Share of economic sectors in the gross domestic product (GDP) from 2010 to 2020. Retrieved from: https://www.statista.com/statistics/578787/share-of-economic-sectors-in-the-gdp-in-philippines/

Pak A, Adegboye OA, Adekunle AI, Rahman KM, McBryde ES and Eisen DP (2020) Economic Consequences of the COVID-19 Outbreak: the Need for Epidemic Preparedness. Front. Public Health 8:241. doi: 10.3389/fpubh.2020.00241

Resnik, D. B. (2020). What Is Ethics in Research \& Why Is It Important? Retrieved from: https://www.niehs.nih.gov/research/resources/bioethics/whatis/index.cfm

Robinson, R.S. (2014). Purposive Sampling. In: Michalos A.C. (eds) Encyclopedia of Quality of Life and Well-Being Research. Springer, Dordrecht. Retrieved from https://link.springer.com/referenceworkentry/10.1007\%2F978-94-007-0753-5 2337

Szmigiera, M. (2021). Impact of the coronavirus pandemic on the global economy - Statistics \& Facts. Retreived from: https://www.statista.com/topics/6139/covid-19-impact-on-the-global-economy/

World Health Organization (2020). Coronavirus disease (COVID-19) pandemic. Retrieved May 12, 2021, from https://www.who.int/emergencies/diseases/novel-coronavirus-2019 